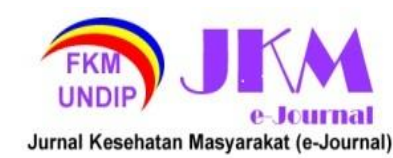

JURNAL KESEHATAN MASYARAKAT (e-Journal)

Volume 9, Nomor 5, September 2021

ISSN: 2715-5617 / e-ISSN: 2356-3346

http://ejournal3.undip.ac.id/index.php/jkm

\title{
HUBUNGAN FAKTOR PERILAKU JUMANTIK TERHADAP KEPADATAN JENTIK DI WILAYAH BINAAN GERAKAN SATU RUMAH SATU JUMANTIK PUSKESMAS CANDILAMA KOTA SEMARANG
}

\author{
Reyzi Hanandita Nariswara ${ }^{1 *}$, Sri Yuliawati ${ }^{2}$, Nissa Kusariana ${ }^{2}$, Retno Hestiningsih ${ }^{2}$ \\ ${ }^{1}$ Peminatan Entomologi, Fakultas Kesehatan Masyarakat, Universitas Diponegoro \\ ${ }^{2}$ Bagian Epidemiologi dan Penyakit Tropik, Fakultas Kesehatan Masyarakat, Universitas Diponegoro \\ ${ }^{*}$ Corresponding author : reyzikrisna@gmail.com
}

\begin{abstract}
ABSTRAK
Penyakit Demam Berdarah Dengue (DBD) merupakan penyakit yang telah banyak dilakukan upaya pengendalian penularannya, namun penularan penyakit ini tetap terjadi. Demam Berdarah Dengue (DBD) ditularkan oleh virus dengue melalui nyamuk betina jenis Aedes aegypti dan Aedes albopictus. Angka kejadian dan angka kematian penyakit demam berdarah dengue (DBD) di Kota Semarang tahun 2019 mengalami peningkatan yang cukup signifikan dibandingkan tahun sebelumnya. Pembentukan Gerakan Satu Rumah Satu Jumantik (GSRSJ) oleh Pemerintah Kota Semarang belum efektif dengan adanya wilayah Gerakan Satu Rumah Satu Jumantik yang memiliki Angka Bebas Jentik (ABJ) yang rendah. Tujuan dari penelitian ini adalah untuk menganalisis hubungan faktor perilaku jumantik dengan kepadatan larva di wilayah binaan Gerakan Satu Rumah Satu Jumantik Puskesmas Candilama Kota Semarang. Penelitian ini merupakan penelitian analitik observasional dengan rancangan penelitian cross sectional yang dilaksanakan pada bulan September-Oktober 2020. Populasi dan sampel penelitian ini adalah seluruh jumantik di wilayah binaan Puskesmas Candilama. Teknik pengumpulan data menggunakan kuisioner dan data yang berasal dari dinas Kesehatan Kota Semarang. Hasil dari penelitian ini adalah faktor perilaku yang berhubungan dengan kepadatan jentik adalah pengetahuan ( $p$-value $=0,02)$, sikap ( $p$-value $=0,01)$, dan praktek ( $p$-value $=$ 0,00). Dapat disimpulkan bahwa pengetahuan, sikap dan perilaku merupakan faktor-faktor perilaku jumantik yang berhubungan dengan kepadatan jentik di wilayah binaan Gerakan Satu Rumah Satu Jumantik Puskesmas Candilama Kota Semarang.
\end{abstract}

Kata Kunci : Aedes aegypti, Angka Bebas Jentik, DBD

\section{PENDAHULUAN}

Demam Berdarah Dengue (DBD) adalah salah satu penyakit menular yang disebabkan oleh vektor nyamuk dan masih menjadi masalah kesehatan di beberapa negara terutama negara dengan iklim tropis salah satunya Indonesia sampai saat ini. Banyak upaya telah dilakukan di untuk mengendalikan penularan demam berdarah, namun, penularan penyakit ini tetap terjadi. ${ }^{1}$

Demam Berdarah Dengue (DBD) ditularkan oleh virus dengue yang memiliki 4 serotipe yaitu DEN 1, DEN 2, DEN 3 dan DEN 4. Virus tersebut ditularkan oleh nyamuk betina dari spesies Aedes aegypti dan Aedes albopictus. ${ }^{2}$

Hampir di setiap wilayah di Indonesia ditemukan kasus Demam Berdarah, salah satunya di Jawa Tengah. Pada tahun 2018 angka kesakitan (Incidence Rate) DBD di Jawa Tengah sebesar 10,2 per 100.000 penduduk, mengalami penurunan bila dibandingkan tahun 2017 sebesar 21,68 per 100.000 penduduk akan tetapi mengalami peningkatan yang cukup signifikan pada tahun 2019 menjadi 24,48 per 100.000 penduduk. ${ }^{3,4}$ Angka kematian (Case Fatality Rate) pada tahun 2018 sebesar 1,05\%, mengalami penurunan bila dibandingkan tahun 2017 sebesar $1,24 \%$ lalu menurun lagi pada tahun 2019 sebesar 1,03\%.3,4

Salah satu wilayah endemis DBD di Jawa Tengah adalah kota Semarang. Angka kesakitan (Incidence Rate) DBD di kota Semarang pada tahun 2017 sebesar 18,14 per 100.000 penduduk, lalu pada tahun 2018 turun menjadi 6,17 per 100.000 penduduk tetapi mengalami peningkatan yang signifikan pada tahun 2019 menjadi 26,37 per 100.000 penduduk. Angka kematian (Case Fatality Rate) DBD pada tahun 2017 sebesar 2,68\% lalu menurun kembali menjadi $0,97 \%$ pada tahun 2018 dan meningkat menjadi 3,18\% pada tahun 2019.5,6 Angka kejadian dan angka kematian demam berdarah dengue (DBD) di Kota Semarang pada tahun 2019 menduduki peringkat ke-5 demam berdarah dengue (DBD) di Jawa Tengah. ${ }^{4}$ 


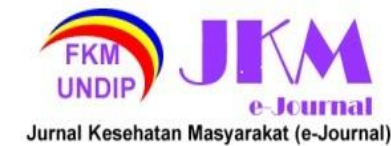

Pada tahun 2017 Pemerintah Kota Semarang membentuk Gerakan Satu Rumah Satu Jumantik (GSRSJ) sebagai upaya pengendalian demam berdarah dengue (DBD) dengan mengambil 1 wilayah tingkat RT sebagai wilayah binaan pada setiap wilayah kerja puskesmas. ${ }^{7}$ Pada awalnya program ini berjalan efektif dalam membantu menurunkan dan mengendalikan angka kejadian DBD di Kota Semarang, akan tetapi pada tahun 2019, terjadi lonjakan kasus demam berdarah di Kota Semarang, dan terdapat beberapa wilayah binaan Gerakan Satu Rumah Satu Jumantik yang memiliki Angka Bebas Jentik (ABJ) yang rendah, salah satunya adalah Puskesmas Candilama.

Kejadian DBD dipengaruhi oleh berbagai faktor yang saling berinteraksi, antara lain faktor agen yaitu virus Dengue, host atau faktor inang dan faktor lingkungan. Faktor lingkungan yang berkaitan erat dengan kepadatan jentik nyamuk Aedes spp. ${ }^{8}$ dan juga penularan DBD adalah keberadaan kontainer atau tempat penampungan air sebagai habitat bagi jentik nyamuk Aedes spp untuk berkembang biak di sekitar tempat tinggal manusia. Sedangkan faktor perilaku yang berpengaruh dengan penularan penyakit demam berdarah dengue (DBD) adalah kurangnya partisipasi dari masyarakat dalam pelaksanaan 3M Plus, serta meningkatnya mobilitas dan kepadatan penduduk. ${ }^{9}$

Tujuan dilakukan penelitian ini adalah untuk menganalisis hubungan faktor perilaku jumantik dalam terhadap kepadatan jentik di wilayah binaan Gerakan Satu Rumah Satu Jumantik Puskesmas Candilama Di Kota Semarang.

\section{METODE PENELITIAN}

Penelitian ini merupakan penelitian analitik observasional dengan pendekatan cross sectional. Penelitian ini menggunakan metode kuantitatif dimana peneliti akan mencari fenomena yang terdapat dilapangan untuk kemudian diperoleh data yang akan diterjemahkan dalam bentuk angka dan selanjutnya akan disajikan dalam bentuk tabel maupun diagram. Penelitian ini dilakukan pada bulan September-Oktober 2020 di wilayah binaan Gerakan Satu Rumah Satu Jumantik Puskesmas Candilama.

Populasi dalam penelitian ini adalah seluruh jumantik di wilayah binaan Gerakan Satu Rumah Satu Jumantik di Puskesmas Candilama di Kota Semarang dengan total 51 jumantik. Sampel penelitian merupakan jumantik, dan besar sampel pada penelitian ini ditentukan dengan sampel total. Teknik pengumpulan data yang dilakukan pada subjek manusia adalah dengan menggunakan kuesioner melalui google form, sedangkan pada subjek kepadatan jentik, pengumpulan data dilakukan dengan mendapatkan data laporan gerakan satu rumah satu jumantik dari Dinas Kesehatan Kota Semarang dan puskesmas terkait.

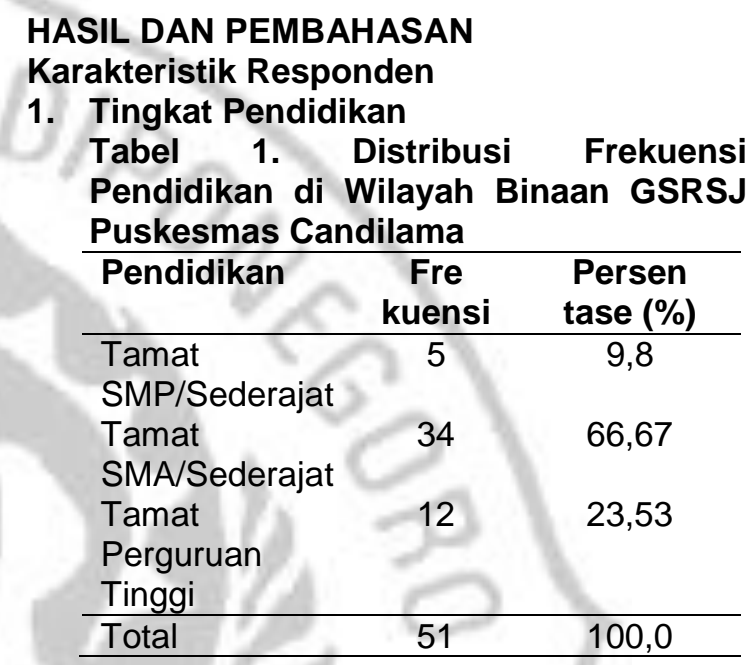

Pada tabel 1 dapat diketahui bahwa proporsi tingkat pendidikan jumantik di wilayah binaan GSRSJ Puskesmas Puskesmas Candilama yang paling banyak yaitu Tamat SMA/Sederajat $(66,67 \%)$ dan responden paling sedikit adalah pendidikan Tamat SMP/Sederajat $(9,8 \%)$

2. Usia

Tabel 2. Distribusi Frekuensi Usia di Wilayah Binaan GSRSJ Puskesmas Candilama

\begin{tabular}{lrr}
\hline Usia & Frekuensi & \multicolumn{1}{c}{$\begin{array}{c}\text { Persentase } \\
(\%)\end{array}$} \\
\hline $26-35$ & 9 & 17,64 \\
$36-45$ & 20 & 39,23 \\
$46-55$ & 17 & 33,33 \\
$56-65$ & 5 & 9,8 \\
\hline Total & 51 & 100,0 \\
\hline
\end{tabular}

Pada tabel 2. dapat diketahui bahwa proporsi usia jumantik di wilayah binaan GSRSJ Puskesmas Candilama yang paling banyak mengisi kuesioner online yaitu 36-45 tahun (39,33\%) dan responden paling sedikit adalah usia 5665 tahun $(9,8 \%)$. 
Analisis Univariat

1. Indeks Kepadatan Jentik (Larva Density Figure)

Tabel 3. Distribusi Larva Nyamuk, House Index, Container Index, Breteau Index, dan Density Figure di Wilayah Binaan GSRSJ Puskesmas Candilama Larva

No Diperiksa Jmlh $\overline{(+)(-)} \mathrm{HI} \% \mathrm{Cl} \% \mathrm{Bl} \%$ DF

1 Rumah $51 \quad 7 \quad 44$

2 Kontainer $20118183^{13,728,9535,29} 3,7$

Berdasarkan tabel 3 dapat diketahui bahwa pada wilayah binaan GSRSJ Puskesmas Candilama House Index sebesar 13,72\%, Container Index sebesar $8,95 \%$, Breteau Index sebesar 35,29\%, dan Density Figure sebesar 3,7.

\begin{tabular}{|c|c|c|c|c|}
\hline & & & & \\
\hline & $m$ & Konta & iner & Persen \\
\hline & TPA & $\begin{array}{c}\text { Jum } \\
\text { lah }\end{array}$ & $\begin{array}{l}\text { Pos } \\
\text { itif }\end{array}$ & $\begin{array}{c}\text { tase } \\
(\%)\end{array}$ \\
\hline & $\begin{array}{l}\text { Bak Kamar } \\
\text { Mandi }\end{array}$ & 51 & 7 & 13,72 \\
\hline & $\begin{array}{l}\text { Kulkas/Dis } \\
\text { penser }\end{array}$ & & & \\
\hline am & Tempat & 5 & 0 & 0 \\
\hline $\mathrm{Ru}$ & $\begin{array}{l}\text { Minum } \\
\text { Burung }\end{array}$ & & & \\
\hline & $\begin{array}{l}\text { Tempayan } \\
\text { /Ember }\end{array}$ & 63 & 2 & 3,17 \\
\hline & Pot Bunga & 10 & 0 & 0 \\
\hline $\begin{array}{l}\text { Luar } \\
\text { Ru }\end{array}$ & $\begin{array}{l}\text { Barang } \\
\text { Bekas }\end{array}$ & 21 & 9 & 42,86 \\
\hline mah & Kolam & 0 & 0 & 0 \\
\hline & Tandon Air & 5 & 0 & 0 \\
\hline Total & & 201 & 18 & 67 \\
\hline
\end{tabular}

Pada tabel 4. dapat diketahui bahwa di Wilayah Binaan GSRSJ Puskesmas Candilama kontainer dengan jumlah positif jentik terbanyak ada pada barang bekas $(42,86 \%)$, dan jumlah positif yang tidak ditemukan ada pada kulkas/dispenser, tempat minum burung, pot bunga.

House index $(\mathrm{HI})$ merupakan indikator yang digunakan untuk memonitoring rumah yang didalamnya positif ditemukan jentik dari total seluruh rumah yang diperiksa. Menurut WHO, suatu wilayah dikatakan berisiko tinggi apabila suatu wilayah mempunyai nilai $\mathrm{HI}>5 \%$, sedangkan berisiko rendah apabila $\mathrm{HI} \leq$ $5 \% .{ }^{10}$ Hasil Penelitian yang telah dilakukan didapatkan bahwa nilai $\mathrm{HI}$ berpotensi tinggi untuk penularan demam berdarah dengue (DBD).

Faktor yang dapat mempengaruhi tingginya nilai $\mathrm{HI}$ adalah perilaku dan partisipasi masyarakat yang masih rendah dalam kegiatan Pemberantasan Sarang Nyamuk (PSN). Selain dari faktor perilaku, dapat dipengaruhi pula dari kepadatan penduduk disuatu wilayah yang dapat mempengaruhi persebaran jentik nyamuk Aedes spp. Jarak antar rumah yang saling berdekatan ini maka semakin mudah nyamuk untuk terbang dari rumah ke rumah karena jarak terbang nyamuk Aedes spp. kurang dari 100 meter. ${ }^{11}$

Container Index (CI) merupakan indikator yang digunakan untuk menggambarkan jumlah penampungan air yang positif larva dari total seluruh tempat penampungan air yang diperiksa. Apabila suatu wilayah mempunyai $\mathrm{Cl}>5 \%$ dikatakan berisiko tinggi terjadi penularan $\mathrm{DBD}$, sedangkan apabila $\mathrm{Cl} \leq 5 \%$, maka dapat dikatakan berisiko rendah terjadi penularan DBD. ${ }^{10}$ Hasil penelitian yang telah dilakukan didapatkan bahwa nilai $\mathrm{Cl}$ berpotensi tinggi untuk penularan demam berdarah dengue (DBD).

Jenis kontainer yang paling banyak ditemukan positif larva berdasarkan data laporan pemantauan jentik dari wilayah binaan GSRSJ Puskesmas Candilama, adalah barang bekas sebesar $42,86 \%$. Barang-barang bekas berupa kaleng bekas, ember bekas, maupun ban bekas ini biasanya sudah tidak terpakai lagi, akan di tata dan diletakkan di luar rumah yang apabila hujan, dapat menampung air sehingga menjadi tempat perkembangbiakan larva. ${ }^{12}$

Nyamuk Aedes spp. cenderung akan meletakkan telurnya pada tempat penampungan air yang memiliki permukaan kasar seperti ban bekas, atau kaleng bekas, serta lebih memilih tempat penampungan air yang berwarna gelap dibandingkan dengan tempat penampungan air yang berwarna terang. ${ }^{13}$

Index yang paling baik untuk memperkirakan kepadatan vektor adalah 


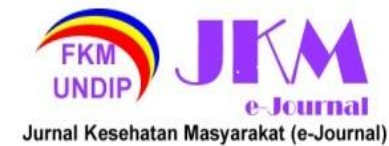

dengan menggunakan Breteau Index (BI), ini karena $\mathrm{BI}$ mengkombinasikan rumah yang diperiksa dengan kontainer yang diperiksa. Apabila suatu wilayah memiliki nilai $\mathrm{BI}>5 \%$ dapat dikatakan wilayah tersebut berisiko tinggi terhadap penularan DBD dan apabila nilai $\mathrm{BI}$ ada pada $\leq 5 \%$ dapat dikatakan wilayah tersebut berisiko rendah terhadap penularan DBD. ${ }^{10}$ Hasil Penelitian yang telah dilakukan didapatkan bahwa nilai $\mathrm{BI}$ berpotensi tinggi untuk penularan demam berdarah dengue (DBD).

Kepadatan populasi jentik (Density Figure) pada suatu daerah memiliki 3 kriteria yaitu : jika angka Density Figure berada pada angka 1 , daerah tersebut dinyatakan memiliki kepadatan jentik yang rendah, apabila berada pada angka $2-5$, daerah tersebut dinyatakan memiliki tingkatan sedang dalam kepadatan jentik, dan apabila berada pada angka 6-9, daerah tersebut dinyatakan memiliki tingkatan tinggi dalam kepadatan jentik. ${ }^{10}$ Hasil penelitian yang telah dilakukan didapatkan bahwa angka Density Figure termasuk ke dalam kategori sedang, yang artinya memiliki tingkat risiko penularan yang cukup tinggi terhadap penularan DBD.

2. Pengetahuan Responden

Tabel 5. Distribusi Frekuensi Tingkat Pengetahuan Responden di Wilayah Binaan GSRSJ Puskesmas Candilama

\begin{tabular}{llc}
\hline \multirow{2}{*}{$\begin{array}{l}\text { Pengetahuan } \\
\text { Responden }\end{array}$} & \multicolumn{2}{c}{ Jumlah } \\
\cline { 3 - 3 } & Frekuensi & $\begin{array}{c}\text { Presentase } \\
(\%)\end{array}$ \\
\hline Baik & 28 & 54,9 \\
Buruk & 23 & 45,1 \\
\hline Jumlah & 51 & 100 \\
\hline
\end{tabular}

Pada tabel 5. menunjukan bahwa jumantik di wilayah binaan GSRSJ Puskesmas Candilama lebih dari setengah memiliki tingkat pengetahuan terkait pencegahan Demam berdarah dengue (DBD) yang baik yaitu sebanyak 30 responden $(54,9 \%)$ sedangkan untuk tingkat pengetahuan yang buruk adalah sebanyak 21 responden (45,1\%).

3. Sikap Responden

Tabel 6. Distribusi Frekuensi Tingkat Sikap Responden di Wilayah Binaan GSRSJ Puskesmas Candilama

\begin{tabular}{llc}
\hline \multirow{2}{c}{$\begin{array}{c}\text { Sikap } \\
\text { Responden }\end{array}$} & \multicolumn{2}{c}{ Jumlah } \\
\cline { 2 - 3 } & Frekuensi & $\begin{array}{c}\text { Presentase } \\
(\%)\end{array}$ \\
\hline Baik & 30 & 58,8 \\
Buruk & 21 & 41,2 \\
\hline Jumlah & 100 & 100 \\
\hline
\end{tabular}

Pada tabel 6 menunjukan bahwa responden di wilayah binaan GSRSJ Puskesmas Candilama yang memiliki sikap dalam kategori baik terkait pencegahan Demam berdarah dengue (DBD) sebanyak 30 responden $(58,8 \%)$, sedangkan responden yang memiliki sikap dalam kategori buruk sebanyak 21 responden $(41,2 \%)$.

4. Praktik Responden

Tabel 7. Distribusi Frekuensi Tingkat Praktik Responden di Wilayah Binaan GSRSJ Puskesmas Candilama

\begin{tabular}{lll}
\hline \multirow{2}{*}{$\begin{array}{c}\text { Praktik } \\
\text { Responden }\end{array}$} & \multicolumn{2}{c}{ Jumlah } \\
\cline { 3 - 3 } & Frekuensi & $\begin{array}{c}\text { Presentase } \\
(\%)\end{array}$ \\
\hline Baik & 30 & 58,8 \\
Buruk & 21 & 41,2 \\
\hline Jumlah & 100 & 100 \\
\hline
\end{tabular}

Pada tabel 6 menunjukan bahwa responden di wilayah binaan GSRSJ Puskesmas Candilama yang memiliki praktik dalam kategori baik terkait pencegahan Demam berdarah dengue (DBD) sebanyak 30 responden $(58,8 \%)$, sedangkan responden yang memiliki sikap dalam kategori buruk sebanyak 21 responden $(41,2 \%)$.

Analisis Bivariat

1. Hubungan Pengetahuan Kader Jumantik Dalam Pencegahan Demam Berdarah Dengue (DBD) dengan Kepadatan Jentik Tabel 8 Hubungan Pengetahuan Kader Jumantik Dalam Pencegahan Demam Berdarah Dengue (DBD) dengan Kepadatan Jentik

\begin{tabular}{cccccccc}
\hline \multirow{2}{*}{$\begin{array}{c}\text { Pe } \\
\text { ngeta } \\
\text { huan }\end{array}$} & \multicolumn{4}{c}{ Kepadatan Jentik } & Jumlah & \\
\cline { 2 - 5 } & $\mathbf{f}$ & $\%$ & $\mathbf{f}$ & $\%$ & $\mathbf{f}$ & $\%$ & $\begin{array}{c}\boldsymbol{p} \text { valif } \\
\text { value }\end{array}$ \\
\hline Baik & 27 & 52,94 & 1 & 1,96 & 2854,9 & \\
& & & & & & & 0,02 \\
Buruk & 17 & 33,33 & 6 & 11,76 & 23 & 45,1 & \\
\hline
\end{tabular}




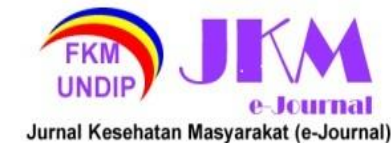

Pada tabel 8. dapat diketahui proporsi responden dengan kategori pengetahuan baik dengan kepadatan jentik padat sebesar $1,96 \%$ dan proporsi responden dengan kategori pengetahuan buruk dengan kepadatan jentik padat sebesar $11,76 \%$.

Pengetahuan responden tentang penyakit Demam Berdarah Dengue (DBD) dan vektor/nyamuk penular demam berdarah dengue (DBD) sangat diperlukan untuk menekan pertumbuhan dan perkembangan jentik Aedes spp. sehingga penularan penyakit Demam Berdarah Dengue dapat dicegah. Sebagai wilayah binaan yang berada di bawah pengawasan langsung oleh puskesmas, setiap jumantik yang ada di wilayah binaan tersebut, sudah dibekali dengan berbagai macam pengetahuan dasar yang berhubungan dengan Demam Berdarah Dengue. Hasil penelitian yang telah dilakukan didapatkan nilai $p$-value sebesar $0,02 \quad(<0,05)$, yang berarti terdapat hubungan yang signifikan antara pengetahuan kader jumantik dalam pencegahan Demam Berdarah Dengue (DBD) dengan kepadatan jentik, dimana sebagian besar responden memiliki pengetahuan yang baik. Hal ini sejalan dengan penelitian Muhammad Rau pada tahun 2019 di Kota Palu bahwa pengetahuan masyarakat tentang pengendalian jentik akan berpengaruh terhadap keberadaan jentik. ${ }^{14}$ Meskipun sebagian besar responden memiliki pengetahuan yang baik, tetapi masih ditemukan jentik di lingkungan tersebut. Hal ini sejalan dengan penelitian yang dilakukan pada tahun 2016 di Kota Mataram bahwa terdapat hubungan yang bermakna antara pengetahuan tentang pencegahan DBD dengan kepadatan jentik Aedes spp. Pengetahuan masyarakat tentang pemberantasan sarang nyamuk yang buruk menyebabkan banyaknya ditemukan jentik di daerah pemukiman. ${ }^{15}$

Responden dengan pengetahuan baik tetapi masih ditemukannya jentik nyamuk dikarenakan sebagian masyarakat kurang memiliki kemauan untuk melakukan pemberantasan sarang nyamuk sehingga meskipun masyarakat mengetahui bahwa keadaan lingkungan rumahnya berpotensi menjadi tempat perkembangbiakan nyamuk Aedes spp. masyarakat akan cenderung membiarkan keadaan tersebut. Sedangkan responden dengan pengetahuan kurang tetapi tidak terdapat jentik hal ini dikarenakan tidak sejalannya pengetahuan dengan tindakan yang berarti bahwa responden tidak memahami tentang tentang penyakit Demam Berdarah Dengue (DBD) dan vektor/nyamuk penular, namun masih melakukan kegiatan pemberantasan sarang nyamuk seperti 3M (Menutup, Menguras dan Mendaur Ulang), karena merupakan rutinitas yang dilakukan dan juga merupakan upaya agar kebersihan lingkungannya selalu terjaga.

2. Hubungan Sikap Kader Jumantik Dalam Pencegahan Demam Berdarah Dengue (DBD) dengan Kepadatan Jentik

Tabel 9. Hubungan Sikap Kader Jumantik Dalam Pencegahan Demam Berdarah Dengue (DBD)dengan Kepadatan Jentik

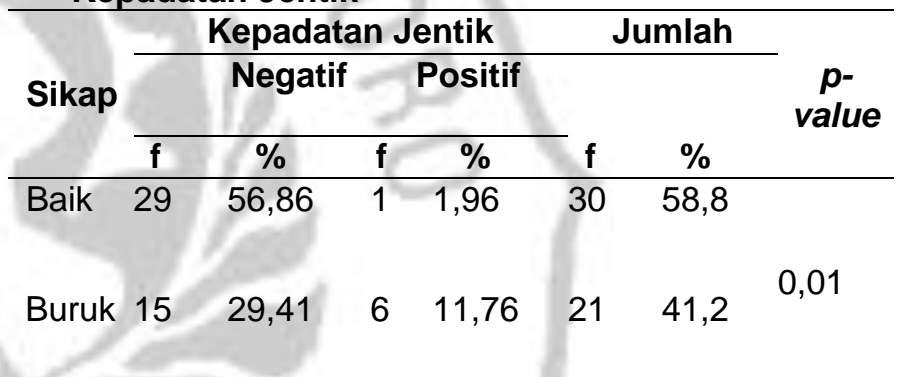

Pada tabel 9. dapat diketahui proporsi responden dengan kategori sikap baik dengan kepadatan jentik padat sebesar $1,96 \%$ dan proporsi responden dengan kategori sikap buruk dengan kepadatan jentik padat sebesar $11,76 \%$.

Sikap seseorang mengenai demam berdarah dengue (DBD) dipengaruhi oleh pengetahuannya mengenai demam berdarah dengue (DBD). Sikap yang mau ikut aktif terlibat langsung dalam upaya pemberantasan sarang nyamuk ditengah kesibukan mereka akan sangat berpengaruh dalam tindakan mereka dalam upaya penanggulangan dan pencegahan penyakit DBD. Hasil penelitian yang didapatkan nilai $p$-value sebesar $0,03(<0,05)$ yang berarti terdapat hubungan yang signifikan antara sikap kader jumantik dalam pencegahan Demam Berdarah Dengue (DBD) dengan kepadatan jentik. Hal ini sejalan dengan penelitian yang dilakukan oleh Ade Pryta pada tahun 2018 di Kecamatan Medan 


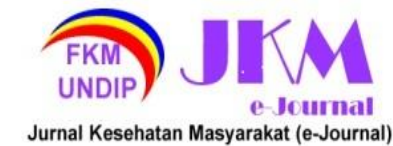

Marelan bahwa terdapat hubungan yang bermakna antara sikap tentang Demam Berdarah Dengue (DBD) terhadap kepadatan jentik. ${ }^{16}$

Responden dengan sikap positif tetapi masih ditemukan jentik nyamuk di lingkungan rumahnya, dikarenakan masyarakat yang memiliki pengetahuan baik akan tetapi cenderung memiliki kesadaran atau motivasi yang kurang atau bahkan tidak ada untuk melakukan kegiatan pemberantasan sarang nyamuk (PSN). Motivasi jumantik adalah dorongan untuk menjadi jumantik dan dorongan melakukan tugas jumantik secara rutin. Hal ini sejalan dengan jawaban responden yang menunjukan sikap tidak setuju apabila diberikan sanksi saat ditemukan jentik di lingkungan rumahnya. Padahal dengan pemberian sanksi terhadap jumantik yang ditemukan jentik di sekitar lingkungan rumahnya, dapat memberikan motivasi tersendiri bagi mereka agar lebih giat dalam melaksanakan kegiatan PSN 3M. ${ }^{17} \mathrm{Hal}$ ini sejalan dengan jawaban responden yang menunjukan sikap tidak setuju apabila diberikan sanksi saat ditemukan jentik di lingkungan rumahnya. Padahal dengan pemberian sanksi terhadap jumantik yang ditemukan jentik di sekitar lingkungan rumahnya, dapat memberikan motivasi tersendiri bagi mereka agar lebih giat dalam melaksanakan kegiatan PSN 3M. Sedangkan responden dengan sikap negatif tetapi tidak ditemukan jentik, hal ini dapat dikarenakan lingkungan sekitar rumah responden yang memang sudah bersih sehingga tidak ditemukan adanya jentik.

3. Hubungan Praktik Kader Jumantik Dalam Pencegahan Demam Berdarah Dengue (DBD) dengan Kepadatan Jentik

Tabel 10. Hubungan Praktik Kader Jumantik Dalam Pencegahan Demam Berdarah Dengue (DBD) dengan Kepadatan Jentik

\begin{tabular}{|c|c|c|c|c|c|c|c|}
\hline \multirow{3}{*}{$\begin{array}{c}\text { Prak } \\
\text { tik }\end{array}$} & \multicolumn{4}{|c|}{ Kepadatan Jentik } & \multicolumn{2}{|c|}{ Jumlah } & \multirow{3}{*}{$\begin{array}{c}p- \\
\text { value }\end{array}$} \\
\hline & \multicolumn{2}{|c|}{$\begin{array}{c}\text { Negat } \\
\text { if }\end{array}$} & \multicolumn{2}{|c|}{ Positif } & \multirow[b]{2}{*}{ f } & \multirow[b]{2}{*}{$\%$} & \\
\hline & $f$ & $\%$ & $f$ & $\%$ & & & \\
\hline Baik & $\overline{3058,8}$ & 82 & & 0 & $\begin{array}{l}3 \\
0\end{array}$ & 82 & \\
\hline
\end{tabular}

Buruk 1427,45 $7 \quad 13,73211,18$
Pada tabel 10. dapat diketahui proporsi responden dengan kategori sikap baik dengan kepadatan jentik padat sebesar 0 dan proporsi responden dengan kategori sikap buruk dengan kepadatan jentik padat sebesar 13,73\%. Setelah dilakukan uji hipotesis didapatkan nilai $p$ value sebesar $0,00 \quad(<0,05)$ yang berarti terdapat hubungan yang signifikan antara praktik kader jumantik dalam pencegahan Demam Berdarah Dengue (DBD) dengan kepadatan jentik.

Praktik yang baik dalam pengendalian jentik nyamuk akan sangat berpengaruh dalam menekan angka kejadian demam berdarah di masyarakat. Salah satu praktik yang semua responden lakukan adalah menguras tempat penampungan air, sekurang-kurangnya seminggu sekali. Meskipun begitu masih ditemukan jentik pada beberapa rumah responden yang mengaku telah melakukan kegiatan menguras tempat penampungan air seminggu sekali. Pelaksanaan kegiatan menguras yang hanya membuang air yang berada di tempat penampungan air yang dianggap sudah kotor kemudian langsung mengganti air tersebut tanpa menyikat tempat penampungan air, sehingga menyebabkan tetap adanya telur nyamuk yang menempel di dinding kontainer dan berkembang menjadi jentik. Hal ini sejalan dengan penelitian yang dilakukan oleh Saleh pada tahun 2018, bahwa meskipun tempat penampungan air telah di kuras, tetapi masih ditemukan jentik nyamuk. ${ }^{18}$

Selain itu masih terdapat responden yang tidak menaburkan abate serta memelihara ikan pemakan jentik pada lingkungan rumah mereka. Menaburkan bubuk abate merupakan salah satu cara yang efektif untuk mencegah munculnya jentik nyamuk pada tempat penampungan air yang jarang atau sulit untuk dikuras. ${ }^{19}$ Selain dengan menggunakan abate, dapat pula menggunakan ikan pemakan jentik. Salah satu jenis ikan pemakan jentik yang efektif adalah ikan guppy (Poecilia reticulate). ${ }^{20}$ Memelihara ikan pemakan jentik dapat membantu menurunkan keberadaan jentik di kontainer, apalagi jika dikombinasikan dengan perilaku PSN yang lain, akan dihasilkan sebuah pengendalian terpadu untuk untuk memberantas jentik vektor penular DBD. 


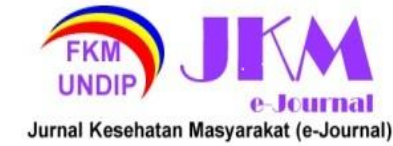

Jurnal Kesehatan Masyarakat (e-Journal)
JURNAL KESEHATAN MASYARAKAT (e-Journal)

Volume 9, Nomor 5, September 2021

ISSN: 2715-5617 / e-ISSN: 2356-3346

http://ejournal3.undip.ac.id/index.php/jkm

\section{KESIMPULAN}

Berdasarkan penelitian yang telah dilakukan di wilayah binaan Gerakan Satu Rumah Satu Jumantik Puskesmas Candilama, Kota Semarang maka dapat ditarik kesimpulan Indeks Kepadatan Larva di wilayah binaan GSRSJ Puskesmas Candilama yaitu House Index sebesar 13,72\%, Container Index sebesar 8,95\% , Breteau Index sebesar 35,29\%, dan Density Figure sebesar 3,7. Pengetahuan, sikap dan praktik jumantik di wilayah binaan Gerakan Satu Rumah Satu Jumantik Puskesmas Candilama dalam pencegahan demam berdarah dengue (DBD) sudah tergolong baik (Pengetahuan 54,9\%, Sikap 58,8\%, Praktik 58,8\%). Variabel yang terdapat hubungan antara perilaku pencegahan demam berdarah dengue (DBD) terhadap kepadatan jentik adalah pengetahuan responden dengan $p=0.02$, sikap responden dengan $p=0.01$, praktik responden dengan $p=0.00$.

\section{SARAN}

Karena masih terdapat jumantik yang di lingkungan rumahnya ditemukan jentik, maka diperlukan adanya teguran berupa sanksi seperti denda kepada jumantik yang di lingkungan rumahnya terdapat jentik, sehingga dapat menjadi motivasi tersendiri bagi para jumantik agar terus menggiatkan kegiatan PSN.

\section{DAFTAR PUSTAKA}

1. Candra A. Demam Berdarah Dengue: Epidemiologi, Patogenesis, dan Faktor Risiko Penularan. Aspirator: Journal of Vector Borne Diseases Studies. 2010;2(2):110-9.

2. Kinansi RR, Widjajanti W, Ayuningrum FD. Kepadatan Jentik Vektor Demam Berdarah Dengue Di Daerah Endemis Di Indonesia (Sumatera Selatan, Jawa Tengah, Sulawesi Tengah Dan Papua). Jurnal Ekologi Kesehatan. 2017;16(1):1-9.

3. Direktorat Jenderal Pencegahan dan Pengendalian Penyakit. Pedoman Demam Berdarah Dengue Indonesia. Pertama. Jakarta: Kementerian Kesehatan Republik Indonesia; 2017.

4. Dinas Kesehatan Provinsi Jawa Tengah. Profil Kesehatan Provinsi Jawa Tengah 2019. Semarang: Dinas Kesehatan Provinsi Jawa Tengah; 2019.

5. Dinkes Provinsi Jawa Tengah. Profil
Kesehatan Provinsi Jawa Tengah Tahun 2018. Semarang: Dinas Kesehatan Provinsi Jawa Tengah; 2019.

6. Dinas Kesehatan Kota Semarang. Data Demam Berdarah Dengue [Internet]. 2020 [cited 2020 Mar 17]. Available from:

http://119.2.50.231/hews/\#rkp_kasus2

7. Direktorat Jenderal Pencegahan dan Pengendalian Penyakit. Petunjuk Teknis Implementasi PSN 3M-PLUS Dengan GERAKAN 1 RUMAH 1 JUMANTIK. Jakarta: Kementerian Kesehatan Republik Indonesia; 2016.

8. Alifariki LO. Hubungan Karakteristik Kontainer dengan Keberadaan Jentik Nyamuk Aedes aegypti di Wilayah Kerja Puskesmas Poasia Kota Kendari. Jurnal IImiah Fakultas Kedokteran. 2017;5(1):388-93.

9. Rusdiyanti $M$, Amanulloh $M$, Krisdayanti E. Metode Survei Kepadatan Jentik Nyamuk Aedes Dengan Pengukuran Density Figure. Jurnal Penelitian Perawat Profesional. 2019;1(1):109-14.

10. Wahyuni T. Monitoring Populasi Nyamuk Aedes Aegypti L. Vektor Penyakit Demam Berdarah Dengue Di Kelurahan Gedongkiwo Kecamatan Mantrijeron Kota Yogyakarta. Kes Mas. 2012;6(1):13-8.

11. Athaillah $F$, Hanafiah $M$, Gumilar A, Fahrimal Y, Karmil TF, Asmilia N. Kepadatan Jentik Nyamuk Aedes spp Di Gampong Peurada, Kecamatan Syiah Kuala, Kota Banda Aceh. JIMVET. 2019;3(4):224-31.

12. Setiyaningsih $R$, Pujiyanti $A$, Hidajat MC, Lasmiati L. Distribusi dan Karakteristik Tempat Perkembangbiakan Aedes aegypti serta Perilaku Masyarakat di Daerah Endemis Demam Berdarah Dengue di Salatiga. ASPIRATOR - Journal of Vector-borne Disease Studies. 2018;10(2):83-92.

13. Budiyanto A. Perbedaan warna kontainer berkaitan dengan keberadaan jentik Aedes aegypti di Sekolah Dasar. Jurnal Biotek Medisiana Indonesia. 2012;1(2):65-71.

14. Rau M, Nurhayati S. Faktor yang Berhubungan dengan Keberadaan Jentik Nyamuk Aedes Aegepty di Wilayah Kerja Puskesmas Sangurara 
(Cross Sectional Study di Sulawesi Tengah, Kota Palu). The Indonesian Journal of Health Promotion. 2020;3(3):212-22.

15. Sanad SM, Suryani D, Cenderadewi M. Hubungan Pengetahuan Ibu Mengenai Demam Berdarah Dengue dengan Tingkat Kepadatan Jentik di Kelurahan Monjok Timur Kota Mataram. Jurnal Kedokteran. 2016;5(2):20-4.

16. Simaremare AP, Simanjuntak $\mathrm{NH}$, Simorangkir SJ V. Hubungan Pengetahuan, Sikap , dan Tindakan terhadap DBD dengan Keberadaan Jentik di Lingkungan Rumah Masyarakat Kecamatan Medan Marelan Tahun 2018 Community Behaviour on DHF in Relationship With Mosquito Larvae Presence in Marelan District Area of Medan. Jurnal Vektor Penyakit. 2020;14(1):1-8.

17. Karyus A, Aziza N. Faktor - Faktor Yang Berhubungan Dengan Kinerja Kader Jumantik Di Wilayah Kerja Puskesmas Segala Mider Lampung Tengah Tahun 2019. Jurnal IImu Kesehatan Indonesia. 2020;1(1):1-10.

18. Saleh M, Aeni S, Gafur A, Basri S. Hubungan Pemberantasan Sarang Nyamuk (PSN) dengan Keberadaan Jentik Nyamuk Aedes aegypti di Wilayah Kerja Puskesmas Pancana Kab. Barru. HIGIENE. 2018;4(2):93-8.

19. Fitrianingsih. Survey Jentik Nyamuk Dan Pemberian Bubuk Abate Di Bak Mandi Warga Rt 03 Rw 03 Desa Mrican Kecamatan Sragi Kabupaten Pekalongan. Journal Bio Education. 2019;4(1):33-40.

20. Salim M, Yahya, Wurisastuti $T$. Partisipasi Masyarakat Dalam Pengendalian Demam Berdarah Dengue (DBD) Di Kelurahan Baturaja Lama Dan Sekar Jaya, Kecamatan Baturaja Timur, Kabupaten Ogan Komering Ulu (Oku), Provinsi Sumatera Selatan. Jurnal Ekologi Kesehatan. 2017;16(2):82-92. 